Gökhan ORHAN 1

PhD, English Teacher, the Ministry of Education

Uşak, Turkey

Prof. Dr. Ömer BEYHAN²

Necmettin Erbakan University, KONYA

Konya, Turkey
Original scientific paper

UDC: 371.32

DOI: $10.5937 /$ IstrPed2101180O

\title{
LESSON STUDY: INVESTIGATION OF ENGLISH TEACHERS' PLANING BEHAVIORS AND PREPARATION ACTIVITIES FOR ENGLISH TASKS IN SOCIAL CONSTRUCTION PRACTICE
}

\begin{abstract}
The aim of the study is to identify and explain preparation activities of three English teachers in lesson study process. The English teachers dealt with activities such as setting objectives, building content, organizing classroom practices and identifying success criteria for learning objectives and reflection in three different lesson study cycles based on social constructivism for about 5 months. In this study, the single case study design was adopted. Criterion sampling method was used to determine the participants. The group-based activities of teachers were repeated in each research lesson at different subjects and different grades. Instead of preparing a new format of the existing lesson plan in each research lesson, the participants prepared new lesson plans for each research lesson. The data were obtained by class observation, camera recordings, interview, and document examination of the lesson plans. It was observed that the teachers made more qualified decisions in planning teaching tasks and there were positive changes in their planning skills and teaching practices in the process in lesson study cycle.
\end{abstract}

Keywords: Lesson study, English teaching, cooperative professional practice, planning behavior, social constructivism.

\section{INTRODUCTION}

According to the principles of constructivism, individuals organize information through a social process by sharing and interacting in a particular social or cultural context (Guba \& Lincoln, 2001). These processes put cooperation and reflection skills forefront among teachers. Teachers should have or develop these skills to positively affect academic success and development of students.

The success of the education programs does not depend solely on the curriculum. It also depends on a careful and thoughtful planning process, cooperation of teachers and determination of levels, expectations and needs of students. English teachers acquired the courses such as method of language teaching, second language acquisition, language assessment academically; however, they have problems in designing the lesson plan and implementing the plan into meaningful activities (Suryani, Rukmini, L.B. Angani, \& Hartono, 2017). The problems have increased the importance of contemporary and cooperative professional development models that encourage teachers to be active (Johnson, 2006). One 
of these professional development models is "Lesson study", which belongs to Japanese educational culture (Cheng, 2011; Fernandez, Cannon, \& Chokshi, 2003; Karabuğa \& Ilin, 2019). A professional learning approach, Lesson study is cooperative knowledge creation process in which teachers work in small groups to plan, teach, observe, reflect and evaluate a set of lessons called "Research lesson" (Cerbin \& Kopp, 2006; Fernandez \& Yoshida, 2004; Yoshida, 1999). The lesson is conducted by a team member whereas the others observe and discuss strengths and weaknesses of the lesson. All team members come together to discuss and revise the lesson (regarding student learning and thinking, lesson objectives and content possible situations and reactions) in post-lesson reflections (Cohan \& Honigsfeld, 2006; Lewis, 2009; Stepanek, Appel, Leong, Mangan, \& Mitchell, 2007). According to Sims and Walsh (2009), lesson study cycle provides teachers opportunities to set short-long term goals, deepen content knowledge, learn and enhance teaching approaches, be self reflective and so improve their teaching skills. Lesson study is also a tool to support teachers to inquiry how students learn and students' thinking process and difficulties they have (Cerbin \& Kopp, 2006). In the literature, some studies (Aimah, Ifadah, Bharati, \& Anggani, 2017; Angelini \& Álvarez, 2018; Collet \& Greiner, 2020; Lee, 2008; Loose, 2014; Meyer, 2006; Nami, Marandi, \& Sotoudehnama, 2016; Reese, 2011; Sponsel, 2010; Tasker, 2014)stressed that teachers are able to plan more effectively by post-reflections and discussions during lesson plan process. However, no studies have looked into English teachers' preparation process and how the teachers prepare for their teaching tasks and how lesson study helps their improvement in planning skills in a cooperative environment. In order to clarify how lesson study contribute English teachers' planning skills for teaching tasks, what teachers do and how they prepare should be explained elaborately in cooperative context.

\section{Objective of the study}

The objective of the study is to define and explain preparation activities of three English teachers for English teaching tasks in the context of lesson study based on social constructivism.

\section{METHOD}

\section{Research Design}

The single case study design was adopted in this study. The case study is a qualitative research method in which the inquirers seek to provide in-depth understanding of a caseor cases (an event, activity, process or individual) as it exists (Büyüköztürk, Çakmak, Akgün, Karadeniz, \& Demirel, 2017; Creswell, 2007). The study aimed to identify and describe the process of three English teachers' planning and preparation for English teaching tasks and changes throughout three lesson study cycles.

\section{Participants}

In lesson study, 3-6 teachers cooperate to develop a detailed plan for a period of time and to observe, reflect and evaluate strengths and weaknesses of the lesson (Stepanek et al., 2007). Lesson study requires dedication and time. This process of lesson study requires some qualifications for participants (a great deal of effort and thought; cooperation, mutual communication, critical judgments between teachers). For this purpose, the criteria sampling method was used to determine the participants. The method allows inquirers to strike appropriate person(s) with specific characteristics (Sönmez \& Alacapınar, 2016). In the 
process of determining participants, the three teachers who were willing and engaged and open to innovation and had critical thinking and communication skills for the study were interviewed. Three participants named Göktuğ, Su and Seçin were included in the study by using the criterion sampling method.

\section{Lesson Study Cycle}

Time is a huge obstacle in lesson study process (Stepanek et al., 2007) because the participants come together to design a detailed plan, observe and revise for a period of time. Firstly, the lesson study team created a schedule for meetings. The team set aside 1 hour for each meeting twice a week to plan research lesson, teach and observe in the classroom, reflect for each lesson study cycle. Then, the lesson study team identified a research theme "Improving students' English communication skills" for three cycles of lesson study which the team considered the students had difficulty. The team determined that research lessons would be conducted in grade 7 on "Making simple comparisons", in grade 5 on "Ability and inability" and in grade 7 on "Making preferences" respectively. Unlike the original form of the lesson study, planning, teaching and reflection processes were carried out once at the determined class levels and on the relevant subjects in order to enable the participants to plan and reflect on different subjects, to ensure the long-term process and the continuity of the participants. For each research lesson, they worked on setting goals, determining content, organizing teaching process (methods, strategies and techniques, activities and materials) and identifying success criteria. A team member taught the lesson and others observed it; the teachers reflected immediately after the lesson and took decisions for next research lesson. The researchers did not manipulate situation except providing place for meetings, transportation of participants, required materials stationery supplies (printer paper, pen, file, etc.) and recording research lessons.

\section{Data Collection}

The data set of the study consisted of semi-structured interview form with teachers, audio and visual recordings of preparation (camera recordings), lesson plans, materials and worksheets, and the examination of observation notes. As a result, the data were obtained as a result of observations and document analysis. It was aimed to increase the validity of the research by providing the diversity of data collection such as observation, and document analysis used in data collection.

\section{Data Analysis}

For the data analysis, all the data resources were transferred to digital form in order to prevent data loss. All the documents were analyzed. Then all camera records (779 minutes and 16 meetings) were transcribed. The researchers developed a data analysis framework based on studies of lesson study (Bozkurt, 2015; Stepanek et al., 2007; Tasker, 2014) and how to design lesson plan (Sönmez, 2015).For coding process, the preparation activities of the teachers were coded. In order to get sub-concepts, all the codes in each part of preparation process (identifying objectives, lesson content, designing teaching process and success criteria) were gathered separately. The coding process was carried out for each research lesson respectively. In consequence of coding process, preparation activities for each research lesson were identified and described. 
Table 1. Data Analysis Framework

\begin{tabular}{|c|c|}
\hline Themes & Explanations and sub-themes \\
\hline \multirow[t]{5}{*}{ Identifying objectives } & Describing learning outcomes \\
\hline & Student behavior oriented \\
\hline & Learning outcome oriented \\
\hline & Cognitive, affective and psychomotor objectives \\
\hline & Consistency of objectives \\
\hline Qualification & Specific and clear \\
\hline \multirow[t]{5}{*}{ Identifying content } & Stating what students should know and be able to do \\
\hline & English concepts, principles and facts to be taught \\
\hline & Suitability level for students \\
\hline & English language skills \\
\hline & Consistence with objectives of the lesson \\
\hline Qualification & Plain or not \\
\hline Types of information sources & $\begin{array}{l}\text { Textbook, internet, additional resources, suggestions, } \\
\text { curriculum }\end{array}$ \\
\hline Designing teaching process & Determining how to present content \\
\hline $\begin{array}{l}\text { Warm-up, presentation and practice } \\
\text { activities }\end{array}$ & $\begin{array}{l}\text { Designing activities for warm up, presentation and } \\
\text { practice }\end{array}$ \\
\hline Strategy, method, technique & Determining appropriate strategy, method, techniques \\
\hline Duration & Determining appropriate duration for activities \\
\hline Materials & Determining materials and the worksheet \\
\hline \multirow[t]{2}{*}{ Possible situations } & $\begin{array}{l}\text { Determining questions to be asked to the student, } \\
\text { expected and unexpected answers; possible positive or } \\
\text { negative situations }\end{array}$ \\
\hline & Consistence with objectives of the lesson \\
\hline \multirow[t]{2}{*}{ Analysis Criteria } & Consistence with content of the lesson \\
\hline & Compliance with the characteristics of the students \\
\hline Qualification & Teaching process and coherence \\
\hline Types of information sources & $\begin{array}{l}\text { Textbook, internet, additional resources, suggestions, } \\
\text { curriculum }\end{array}$ \\
\hline Success criteria & Determining success criteria \\
\hline Analysis Criteria & Consistence with objectives of the lesson \\
\hline Qualification & Specific and clear \\
\hline
\end{tabular}

\section{FINDINGS}

\section{First Research Lesson (Lesson Study Cycle I)}

In the first research lesson, the teacher developed a plan on "Making simple comparisons" with "Appearance and Personality" unit theme for grade 7. The teachers decided to prepare a powerpoint presentation for the warm-up section (in order to attract students' attention and evaluate their readiness) and present section (to teach the structure of comparatives implicitly); an educative game for practice section (to reinforce the structure and to improve communicative skill). The teachers determined the main objective of the first research lesson as "Students will be able to develop communicative skills by talking about differences". For each section of the lesson, the team set objectives separately (e.g. "The teacher lets the students learn by themselves with the help of the examples in the presentation). It was observed that the main objective was related to student behavior; objectives for sections of the lesson included teacher behaviors-oriented statements conversely. The teachers did not have a common expression in writing objectives (e.g. students will be able to... for main objective; "To attract.../ Teachers let... for warm up and practice objectives respectively). 
Cognitive, affective and psychomotor domains were considered to set objectives. For instance, an affective objective "To attract students' attention and evaluate their readiness" was set to aim at attracting students' attention to the lesson in warm- up section. It was seen that objectives set by the teachers were general not specific and did not cover English skills comprehensively. The teachers underrated setting the objectives; moreover, they were not fully aware of how to write the objectives. The teachers carried out setting objectives process, after talking and deciding on the content and activities:

Seçin: We should not practice the activity at the end, we will use another activity with pictures there.

Su: Your students have a bit knowledge of the structure ... I don't think it takes much time for them to adapt to the game.

Göktuğ: It is logical

Seçin: What is the objective of this section? By teaching implicitly

Göktuğ: Students' intuition

Seçin: Let's write "To present the subject to the students by implicitly"

Göktuğ: Yeah

Seçin: Then 15 minutes to this ... for game 20 minutes.

Göktuğ: When will we present the lesson?

$$
\text { ( } 1^{\text {st }} \text { Research Lesson, } 2^{\text {nd }} \text { Meeting) }
$$

On identifying the lesson content, the teachers regarded the subject matter as "Making simple comparisons". The team did not utilize the curriculum published by the state and therefore the teachers did not make the extent of subject matter relevant and identify which of this grammatical structure's rules (one syllable, two or more syllables, and irregular adjectives) would be transferred to the students.

Seçin: Last week we did not mention about irregular adjectives in comparatives. Will we teach?

Göktuğ: To me... We can only give some examples

Su: Anyway, we will teach implicitly so we can give some examples

Göktuğ: The unit is about "Physical Appearance" and there are no irregular adjectives but if you like we can teach

$$
\text { ( } 1^{\text {st }} \text { Research Lesson } 3^{\text {rd }} \text { Meeting) }
$$

The teachers designed the lesson according to the principles of the communicative language method, which focuses on the development of communication skills for the research theme. For example, it was aimed at enabling students to make inferences from sample sentences in the teaching of the grammatical structure rules of "Comparatives" in the present section:

Göktuğ: Encourage the students develop comparatives from sample sentences?

Su: Making sentences

Seçin: Making sentences (writes in the plan). Are we going to draw attention to the Comparatives section in intonation? Let's write it

Su: With both intonation and writing.

Seçin: When writing sentences on the board with intonation ... (writes on the plan) and what to say

Göktuğ: With its intonation 
Su: Underline the structure or writes it with a different pen

Seçin: Highlight the structure...

Su: It makes them aware of the structure, and the students start to make the rules themselves?

( $1^{\text {st }}$ Research Lesson, $2^{\text {nd }}$ Meeting)

For the duration of the activities, the teachers decided 5 minutes for the warm up; 15 minutes for present and 20 minutes for practice. The teachers made concentrated on preparation and use of the material in the first meeting, but in the following meetings, the teachers frequently gave their opinions on the design of these materials and the choice of visuals. The teachers focused on teaching materials by giving importance to the use of smart board but they did not distribute a material such as a worksheet and they did not conduct a preparatory study on the questions that would encourage students to think. The teachers focused on positive expectations (students' correct order of concepts, making sentences correctly) in the first research lesson preparation process in general. In spite of the students' possible answers, the teachers did not carry out a detailed practice on how and in what way they could correct misunderstandings and incorrect sentence constructions of students:

Su: What will the teacher do here? (Teacher response); if student make the sentences faultily; the teacher can warn and say motivational words

Göktuğ: Will the teacher meddle while playing games? Yes

Su: The teacher will say "Think again, be careful.

Seçin: You will give some clues or we can write it when needed; we can include it

Göktuğ: Ok

( $1^{\text {st }}$ Research Lesson, $4^{\text {th }}$ Meeting)

The main success criterion was regarded as "If the students say the adjectives expected easily, the students use the structure correctly and the groups support their contestants and don't blame each other, the lesson will be successful" by taking into account the activities rather than the objectives in the warm up, present and practice sections. The teachers determined success criterion by only taking into practice of the students in the activities and their answers account:

Göktuğ: What are our success criteria? How will we evaluate our plan?

Seçin: Exactly

Göktuğ: We will say that our plan will be successful if these come true in the course.

Su: If they find adjectives easily

Göktuğ: Exactly

Seçin: I write

Seçin: How well they do in practice, it also matters

Göktuğ: Then students use the structures correctly.

( $1^{\text {st }}$ Research Lesson, $4^{\text {th }}$ Meeting)

The first research lesson was conducted by Göktuğ teacher and the others observed the lesson in the classroom. During the course, the teacher switched to deductive teaching: 
Göktuğ Teacher: Tom is fat (writes on the board). So what do we say if we make a sentence for Mike?

Student: .. fatter than Mike (fat from Mike)

Teacher Göktuğ: When we compare the two people, if we are talking about more and then we want to specify the other person, we associate them with "than".

(Implementation of $1^{\text {st }}$ Research Lesson)

The research theme was carried out between the teacher and the student, but not between the student and the student. Only three sample sentences were given and in-depth questions for students were not asked. It was observed that the whole class was not active in the present section;the students who answered incorrectly were not given the opportunity to find their mistakes themselves:

Göktuğ Teacher: (He writes on the board and circles the word more) Why did we use "more"?

Student 1: To give meaning of "more"

Göktuğ Teacher: But we did not use the "-er" tag. Why is that? (Gives another student the right to speak)

Student 2: Because it is a long word.

(Implementation of $1^{\text {st }}$ Research Lesson)

In reflection process, the teachers evaluated the lesson pertaining to the general success of the lesson plan as successful, but as unsuccessful regarding targeted research theme. It was detected that one-way (teacher-student) communication did not satisfy teachers very much, and some problems in planning such as timing and visual design were noticed by teachers. On grammar structures, the teachers evaluated the course as successful, but could not get a satisfactory feedback on the focus of activity design and communication skills:

Researcher: Was the lesson successful or not according to the plan?

Seçin: Was successful except for timing

Göktuğ: I think so. The rest is successful

Su: We believe we have reached our theme. Students said the adjectives we expected "tall, short" we achieved this, but there were few examples in present, this goal was not fully achieved in the full present section.

Seçin: The plan met the objective, but as a whole I'm still not satisfied. I wanted them to communicate with each other.

Göktuğ: I said that

(Reflection of $1^{\text {st }}$ Research Lesson)

The teachers made the decisions for the second research lesson pertaining to planning, and especially the issues that negatively affected the timing process.

\section{Second Research Lesson (Lesson Study Cycle II)}

The teachers developed a lesson plan on grammar structure "Ability and Inability" for 5th grade English course. The second research lesson was completed after six meetings (314 minutes).For warm-up, the teachers focused on reminding English words through an original video created from short sections of cartoons. The teachers designed two activities for the 
present section. In the first activity, the teachers aimed to focus on exploring the positive, negative and questioning forms of the use of "Can-can't" by two visuals depicting ability and inability. In the second activity, a worksheet with 11 questions (supported by visuals) was designed. The teachers decided to design a game-based activity consisting of 16 visual sets and covering questions "Can I..? / what can I do?" and "Yes, you can" "No, you can't" "You can..." which based on a guessing game for practice section.

The teachers considered main objectives as "Students will be able to ask and answer questions about ability and inability" and "Students will be able to express their abilities and inabilities by writing"; for warm up "To make the students remember the words related to games and hobbies", for present "The students will be able to discover the structure and use it /To reinforce the structure" and for practice "To revise the structure by using in a game/To enable students try to make sentences actively/To improve students' communicative skills by asking and answering questions about the structure and allow them to have a good time together". The main objectives included student- behaviours but some objectives in warm up and practice section did not. These goals were predominantly on "Speaking skills" and "Writing skills". The teachers attached more importance to determining objectives than the previous preparation process but they did not use a common expression in writing objectives. The teachers expressed objectives of the lesson in detailed, clear and precise statements (e.g. "the statement "their own"):

Seçin: Goals of the study lesson...

Su: In the first research lesson, We had weakness of writing objectives? We need to make the objectives clearer and more specific.

Göktuğ: Yeah we should clarify

( $2^{\text {nd }}$ Research Lesson, $1^{\text {st }}$ Meeting)

In the process, the teachers took into account students' levels and individual characteristics in determining objectives:

Seçin: You say the children are bit unsuccessful or maybe they will hesitate to

say

Su: Yes

Seçin: You will have to force them; maybe 15 minutes

Su: Some of my students are very good but shy kids

Göktuğ: I got it. But they participate in lesson when they play the game.

$\left(^{\text {nd }}\right.$ Research Lesson, $2^{\text {nd }}$ Meeting)

The teachers set cognitive, affective (interest, attitude and student feeling towards having fun) and psychomotor objectives (to enable students to speak effectively and develop communication skills) but predominantly for cognitive learning areas. The teachers determined the content of the lesson before general objectives. After finishing identifying the content, the teachers stated objectives in practice section:

Göktuğ: It is ok

Seçin: Present section[first part] is complete.

Su: Okay. We did not write our objectives

Seçin: What is the purpose of this section? 
The teachers also set some goals for their own teaching processes such giving clues to the students where necessary in order to speed up the process, ensure full student participation, and focus on the process rather than learning outcomes:

Seçin: Now, think about it, we'll want the students to make sentences and you won't do everything by yourself. Consider the students!

Su: They do

Seçin: Do they do?

Su: Now, participation is important in the process. We don't pay much attention to "Accuracy". The students predict at least, I'll help them. I'm in control of the lesson. If they don't understand, I'll help by some tips.

Seçin: If the student does not remember a word, you help the word

( $2^{\text {nd }}$ Research Lesson, $4^{\text {th }}$ Meeting)

For the content, teachers wanted the students to use the structure "Can can't" and "Can s / he / you ... and "What can s / he / you do?". The main content was identified as "Revising words related to games and hobbies/Discovering ability and inability by using the words related to games and hobbies/Expressing/making sentences about ability and inability/Asking lanswering questions about ability and inability". Speaking, writing and listening skills were focused in the content. It was concluded that the main and section contents were compatible with the main and section (activity) objectives, and the teachers tried to do that elaborately and carefully:

Seçin: Content of the unit. We should design the content carefully. The other sections will be formed in accordance with this part.

Göktuğ: Can we express "Expressing ability and inability"? and we will link it to games?

Su:Yeah...

( $2^{\text {nd }}$ Research Lesson, $1^{\text {st }}$ Meeting)

The duration determined for this subject in the English curriculum is 3 lesson hours (1 week), however the teachers aimed to teach the content in just 40 minutes. In this regard, it was understood that the prepared content was more intense than the English curriculum. Although the teachers stated that the content was intense in the conversations, they did not attempt to simplify the content:

Su: The whole unit will be taught in just 1 lesson hour

Göktuğ: That is. It can be intense for the students

Su: We make time

Göktuğ: Yeah

$\left(^{\text {nd }}\right.$ Research Lesson, $5^{\text {th }}$ Meeting)

The teachers did not use any sources such as the English curriculum or the internet while designing the content of the second research lesson. It was clear that teachers planned the content by their past experiences and habits. In order to determine the activities, the teachers decided to prepare mentally before meetings and come up with reasonable suggestions:

Su: Are the activities gotten over in the next meeting?

Göktuğ: It becomes revealed 
Su: Let's come up with an idea

Göktuğ: We will make a list and Seçin from there.

( $2^{\text {nd }}$ Research Lesson, $1^{\text {st }}$ Meeting)

It was observed that the teachers thought in detail and focused on making the activities special. For example, Göktuğ teacher came up with the idea of designing a special video. Teachers made an effort to get out of the usual lesson via materials of activities:

Seçin: Can we allow these students to have fun? I think it can be a video or a song,

but presenting the image and directly asking for the word bore the students $a$ bit

Su: And it can be simple, right?

Seçin: Yes

Göktuğ: Let's make a video

Seçin: Like how?

Göktuğ: We can Seçin images and make videos. I will do it

( $2^{\text {nd }}$ Research Lesson, $2^{\text {nd }}$ Meeting)

The teachers held a discussion to encourage the students to be active during lesson. The teachers ensured that students would participate in the lesson and communicate with each other by taking into account student characteristics, interests and attitudes. For instance, the team made decisions to enhance the warm-up activity and to attract students' attention:

Su: Some of my students are very hardworking but shy kids

Göktuğ: I understand, but when it comes to play, they participate.

Seçin: These are 5th grade and I think we can make it more fun, maybe a video, maybe a song, but presenting the visuals and asking for the word directly is a bit boring Su: It's a little simple, right?

Seçin: Yes

$$
\text { (2 } 2^{\text {nd }} \text { Research Lesson, } 2^{\text {nd }} \text { Meeting) }
$$

It was detected that the teaching process (activities in sections) were interrelated with each other; the previous activity comprised a basis for the next activity; the activities reinforced each other:

Seçin: They will reinforce the words

Göktuğ: So, Our aim is to go from narrow to broad, first they will learn the words, they will make "Can can't" sentences by using the words and finally they will play a game by words and "can can't". I think it sounds good. The order would be fine

Su: OK

Göktuğ: Say if there is unreasonable something,

Su: It is fine for me, but we thought that if we give the same words in each section, the time can run fast. At game...

$$
\text { ( } 2^{\text {nd }} \text { Research Lesson, } 3^{\text {rd }} \text { Meeting) }
$$

The teachers adopted the communicative language teaching method, which prioritizes the communicative process, grammatical accuracy and development in order to achieve the 
objectives of the research theme. 5 minutes for the warm up activity, 25 minutes for the present activity and 10 minutes for the practice were determined guessingly. They only tried to determine the duration process more clearly and accurately by performing (how much time to be allocated to each word):

Göktuğ: While I was coming today, I thought about how it would be for 10 seconds and they might be bored with every word. Now we will limit 10 seconds for each word

Su: Well

Göktuğ: Children can be bored.

Su: Yes.

Göktuğ: Let's keep time (10 seconds). Look, are you bored too?

Seçin: Yes, when you think it's long time

(2 ${ }^{\text {nd }}$ Research Lesson, $3^{\text {rd }}$ Meeting)

The possible positive and negative situations were noted in only present section by focusing on a negative possibility of adding "-ing" to the main verb that came after the "can" structure and misperception of visuals in the worksheet to be distributed to students. The teachers discussed on only possible positive situations for the warm up and practice activities. The reactions of the teachers to the students' possible questions were not very detailed, they made decisions to ignore mistakes and correct it without any explanation or direction:

Su: I won't explain there and I will correct it as "She can ride a horse." The explanation lasts for a long time.

Göktuğ: It takes a long time to explain there, you may go crazy

Su: I only correct it without explaining

Seçin: Teacher says the correct sentence

( $2^{\text {nd }}$ Research Lesson, $4^{\text {th }}$ Meeting)

In the process of determining success criteria, the teachers focused on both section activities and overall lesson success and the teachers determined the goal-oriented success criteria based on the activity goals. "If the students' attention is attracted; If the students try to use the structure and make sentences willingly; If the students behave respectfully to each other and the students have fun during the game; If the students take part in the game eagerly the students ask and answer to communicate with each other in the target language" were success criteria of the research lesson. In the sense, it was seen that success criteria were related activities and student learning but not the research theme and the teachers set different criteria such as "Being respectful, having fun and willingly participating in the process". The second research lesson was taught by Su teacher. During the lesson, the most notable situation was the answer "Yes, I can" "No, I can't" to the question "Can s / he...?" and the answer "I" and "No, I don't to the question "What can s / he do?" of the students. Su teacher alerted the students to be aware of their mistakes by giving clues.

In reflection process, the teachers evaluated the lesson successful with regard to participation and reactions of the students and two-way communication but as unsuccessful regarding the use of the relevant structure and the correct use of "I, you, he, she" subjects in questionanswer activities:

Seçin: Our timing in warm up was good, I think we have achieved our goal 
Göktuğ: It happened

Seçin: As an evaluation, I think all the students raised their hands and they were eager.

Seçin: I think they acquired the structure

Göktuğ: They learnt accurately

Seçin: They were able to make sentences but we made a mistake. If we had taught the "I you we they" group first and then showed "he she it" group afterwards, they would not make mistakes because "what can you do" in asking questions and getting answers, they started to answer them with "yes, she/ he".

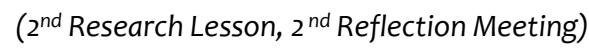

The teachers made decisions to make the content simpler and analyze pre-learnings of the students for lesson planning for the next research lesson.

\section{The Third Research Lesson (Lesson Study Cycle III)}

The teachers held five meetings (259 minutes) for the third research lesson. The teachers aimed to teach the functions "Making simple preferences" for grade 8. For warm up section, the teachers decided to re-evoke the words the students learned in the past years and teach new understandings. For present section, teachers decided to give the structure "I prefer [noun] to [noun]; verb usage "I prefer verb + ing to verb + ing", common verb usage and the question "Which one do you prefer?" via a PowerPoint presentation. For practice section, they enabled the students to apply the given words and structures in precious sections through a communicative-oriented dialogue activity. The teachers set the general objectives as "Students will be able to state their preferences in a communicative way", "Students will be able to ask and answer about their preferences by interacting with each other", "Students will be able to express their opinions related to their preferences by making dialogues in groups" and "Students will be able to understand an oral text in a communicative way. It was observed that teachers brought "Speaking skills" to the fore by mainly using the concepts of "Communicative way" and "Interactive way (interaction)" in their objectives sentences. The teachers emphasized the development of communication skills by setting goals for expressing their opinions about their preferences through dialogue and understanding a non-literary text, asking questions and answering and expressing their own preferences much more. The teachers expressed the objectives of the lesson in a detailed, clear and certain expression. For the first time, teachers exchanged ideas among themselves on how to express and write general objectives:

Seçin: Should we write "to" when writing goals? I always write "Students will be able to" If we write here as a student-oriented, then I think we should write "will be able to".

Su: We wrote "will be able to" in the first meetings?

Göktuğ: Let's write it as "Students will be able to ...".

(3 $3^{\text {rd }}$ Research Lesson $3^{\text {rd }}$ Meeting)

It was clear that the general goals were compatible with the activity goals (e.g. the present activity, "The students will learn the structure and try to use it eagerly" and "Students reinforce the new structure by the help of writing and speaking skills"). In this regard, it was seen that an objective sentence that only reminds the relevant concepts in warm up activity 
was not included in the general objectives. It was certain that the general goals and activity goals were student behavior oriented (e.g. students will be able to...). The Cognitive, affective and psychomotor objectives were available in the objectives and the teachers set the psychomotor objectives mostly for improving communicative skills. The teachers determined the activities and content to be carried out before the general goals of the lesson. In the preparation activities for the third research lesson, the teachers set goals for their teaching tasks such encouraging unwilling students by walking around the classroom; involving all students in the process; focusing on the process rather than errors as. The teachers decided that the content needed to be simple and detailed in the preparation process of the third research lesson due to the intensive content of the second research lesson by getting help from the coursebook and the internet. The content covered "Expressing preferences" and "Expressing personal thoughts related to their preferences". They decided to limit the "Prefer" structure to only positive and questioning forms for the "I and you" subjects, not processing negative and questioning forms about the use of "He, she and it" subjects in order to keep the content simple and avoid confusion. It was observed that the teachers were in an effort to create a clear and distinctive content:

Su: I think the 2nd plan was good in general, only the issue was intense.

Seçin: Shall we say "They talk about their own preferences"?

Göktuğ: It is ok

Seçin: If we narrow it down that way, I don't think it is necessary to include

"He/she" subjects.

Göktuğ: Should we include those subjects or not?

Seçin: I think we shouldn't get into them

Su: Let's not enter

Göktuğ: Are we going to give it directly with the subject l?

Su: There is a" $-s$ ", they forget it or something.

Seçin: Yes, there is "Does/doesn't" and then we need to teach

( $3^{\text {rd }}$ Research Lesson $2^{\text {nd }}$ Meeting)

The teachers made an effort to achieve the consistence between the content and the objectives of the lesson by revising the objectives. It was also seen that the teachers took into account of pre-learning and previous acquisitions in the curriculum:

Seçin: Let's open a parenthesis here. While we are thinking about whether we should give the "I think" patterns or not, we wrote it in our objectives but

we...

Su: Did we write that "the opinions"?

Seçin: We said "Expressing personal opinions"

Göktuğ: Then we do something

Seçin "Students will be able to express their personal opinions

Göktuğ: "After showing "I Prefer" structure, we will give an example and we

will do question and answer on the board.

Seçin: And aren't these 7th grade?

Göktuğ: They are

Su: I think so

Seçin: They learnt "I think" in previous academic year (grade 6)

Göktuğ: They can achieve. 
As for that, it was found that the course content determined was appropriate in terms of time and student levels and the two course hours specified in the English lesson curriculum were appropriate for the forty-minute period. During the third research lesson, it was observed that the teachers reflected on how to design the activities and exchanged ideas due to the activityoriented lesson processing purposes. In the warm up section, the teachers looked at the applications on the internet, textbook and digital education platforms for the design of the activity. The teachers did not find a material that included the given content and the concepts and they conducted an original video creation study. In the present section, the teachers applied the presentation activity they had done in the previous research courses for this course as well. At the end of the present activity, they aimed to use the time effectively in the dialogue process (in practice) and to make the activity more fluent by distributing a worksheet containing a general repetition of the lesson.

Although they expressed different opinions, the teachers made group-based decisions. During practice process, it was observed that the teachers thought in detail about the expressions to be used in the lesson process, the answers given by the students and how the teachers would explain the activity instructions to the students. Regarding to possible situations, the teachers generally reflected their expectations of positive responses from students. In the development activity, they envisioned a possible negative situation in ungrammatical usage such as use of "-ing" and "to" in verb usage. Unlike the previous research lessons, they did not ignore the possibility of a possible situation that the students might act unwillingly:

Göktuğ: There is nothing we can do [practice] here. Come on, imagine that the students would be unwilling people, what will we do?

Su: As we said, if they are unwilling, we can state the situation in an evaluation process.

Seçin: I think the teacher motivates the students if such a situation occurs "Come on, you can do it"

$$
\text { (3 } 3^{\text {rd }} \text { Research Lesson } 4^{\text {th }} \text { Meeting) }
$$

During the third research lesson, the teachers did not express their reactions to the wrong or incorrect use of grammar structure in detail. They did not give any explanation or direction in this regard. The teachers adopted the same teaching method as in the previous lessons. In the process of determining the timing, they determined a process of 5 minutes for the warm up activity, 15 minutes for the present activity and 20 minutes for the practice. The teachers took a decision to apply an alternative game activity in order to successfully complete the course despite the possibility of ending the course early according to the determined process:

Göktuğ: If the dialogues end early

Seçin: We can apply Jeopardy [word game].

Su: That's a good idea.

(3 $3^{\text {rd }}$ Research Lesson $4^{\text {th }}$ Meeting)

It was understood that the materials prepared by the teachers were directly related to the content and objectives of the course. In the process of determining success criteria for the third research lesson, they focused on both the course stages and the overall course success. Some success criteria of the third lesson were "If the students try to say the words actively and willingly; If the students use the structure correctly and eagerly; If the students act fluently; If the students work willingly during practice section; If the students act their 
dialogues fluently; If the students can write meaningful sentences about their preferences; If the students speak about their preferences with correct pronunciation the lesson will be successful". It was detected that the success criteria of the warm up, present and practice activities were directly related to the activity objectives. When determining the success criteria, the teachers took the factors such as showing interest, participation, willingness and effort in the course as well as the lesson objectives as evaluation criteria. For example; it was concluded that the willing and active participation of students and their participation in activities without getting bored during the introduction and development activities are considered as success criteria:

Göktuğ: The purpose of the warm up is to draw attention, but should we evaluate the success of the video?

Su: But the purpose of the warm up is to remind words?

Göktuğ: What if the students watch outside rather than watching video?

Seçin: We need to consider a general evaluation here.

Göktuğ: Okay then

Seçin: Let's say "Try to use the structure correct [the students], maybe they can't use it properly, but they can try.

Göktuğ: Okay

(3 $3^{\text {rd }}$ Research Lesson $4^{\text {h}}$ Meeting)

Unlike the previous research lessons, teachers decided to write as a psychomotor assessment criterion to evaluate students' speaking skills with correct pronunciation:

Seçin: We evaluate speaking skills with correct pronunciation and fluency

Su: They should pronounce the words properly

Seçin: They speak about their preferences with the correct pronouncaition

Göktuğ: OK, I write that way

$$
\text { (3 } 3^{\text {rd }} \text { Research Lesson } 4^{\text {th }} \text { Meeting) }
$$

The third research lesson was conducted by Göktuğ teacher in the classroom. The lesson was taught in the target language (English) predominantly. The teacher taught the lesson in the target language. The teacher only took a guiding role by putting the students at the center throughout the lesson process. For this purpose, the teacher showed a guiding and supportive attitude in order for the students to reach the rules regarding the relevant grammar structure themselves. The teachers stated that the third research lesson was more successful than previous lessons owing to an intensive English communication process, fluent dialogues, and active participation of students. On the theme of the research, they stated that the students communicated with each other and that each student could express themselves in the lesson.

Göktuğ: I think there were no students who did not speak at all, even the most unsuccessful student made a sentence. In the second part of the present section, after the volunteer students refrainer students also raised their hands

Su: The structure was learnt properly and communication and harmony both is also important.

Seçin: So

Su: They even supported each other in making dialogue 
Göktuğ: I agree.

\section{( $3^{\text {rd }}$ Research Lesson, $1^{\text {st }}$ Reflection Meeting)}

The team stressed the simpler content design played an important role in the success of the lesson:

Seçin: Our biggest fault in the previous plans, especially the plan of the 2nd lesson, was that we prepared intensive content and we aimed to teach too many topics. There was also confusion in the second unit, now we only dealt with "I prefer" and "Which one" and there was no confusion. The children understood very clearly what to do. They used it accordingly. The content was well prepared.

Su: We also included all skills here.

(3 ${ }^{\text {rd }}$ Research Lesson, $1^{\text {st }}$ Reflection Meeting)

\section{DISCUSSION AND CONCLUSION}

In the early stages of preparation process, it was observed that the teachers did not elaborate on goal setting and they set their goals according to the activity and content. The teachers had difficulties in determining clear and specific objectives and writing objectives. It is thought that the most important reason of these problems experienced by teachers may be the lack of knowledge and experience in lesson planning. The teachers' past habits such preparing the lessons mentally and not making a detailed lesson plan as and experiencing the research lesson process for the first time are considered as other factors. During the goal setting process, teachers ignored student characteristics, students' pre-learning and readiness levels as well. The findings are agreement with the studies of Taylor (1970), Zahorik (1975), Peterson, Marx, and Clark (1978), Yinger (1980), Yildirim (2003), Yetkin-Özdemir, Akdal, Bozkurt, and Gürel (2015)and Bozkurt (2015). The studies pointed out the teachers set the objectives after determining content, activities and materials and have difficulties in determining objectives. It was observed that teachers set more specific objectives in the process towards their own teaching tasks (speaking Turkish in order to save time, not seeing mistakes in communication, focusing on the process; encouraging students). During objectives setting process (third research lesson), it was observed that the teachers displayed clearer and more specific behaviours towards setting objectives and set more specific objectives in the process towards their own teaching tasks. In the studies conducted by Huang, Su, and Xu (2014), Bozkurt (2015), Aykan (2019), Collet and Greiner (2020), teachers set more specific and clearer objectives during the research lesson process. During the process, teachers focused more on affective and skill-oriented psychomotor goals such as students' interests and attitudes. As the process progressed, the quality of the success criteria was improved by considering students' affective (willingness, fun) psycho-motor (fluent speaking and communication) social aspects (respectful behaviour, not being offensive). Being able to set more realistic goals and taking the research theme as a basis can be considered as an important factor in the change of these success criteria. These findings comply with the studies of Bozkurt (2015) and Aykan (2019) finding out teachers create more comprehensive and in-depth success criteria during the course research process. Of the most extensively case discussed by teachers in evaluation and reflection process was content determination. The teachers had difficulty in content determination and attributed the unfavourable and unsuccessful situations experienced in the first and second research courses to the inability to determine. The failure to determine pre-learning and teachers' habits of determining content for their usual lessons are considered to be an important factor. The group members avoided 
pursuing their lesson planning habits as a result of group members' thoughts and reflection processes and determined more suitable content for the students' level and the curriculum by utilizing the textbook and internet. Kükey (2018) and Collet and Greiner (2020)found out that English teachers are able to determine simpler content regarding the teaching of grammar structures in the course of lesson study. In this regard, this finding is consistent with the studies mentioned.

In relation to the organization of teaching experiences, it was appeared that teachers spent most of their time on determining the activities during the lesson stages. Apart from activity design, they focused on the material and timing process for the activities. During the lesson study process, it was observed that teachers developed more original and different activity stages than the preparation for a routine lesson implementation. It can be said that they designed activities by considering subject and goal suitability, students' interests. The teachers increased their motivation to prepare a different and better lesson in the process. Gök (2016) revealed that the lesson study process increases the motivation of English teachers and encouraged them to try different activities and better understand student needs. Nami et al. (2016) pointed out English teachers display positive behaviours towards presenting the lesson and organizing necessary activities during lesson study process. Regarding the preparation of questions to be asked to students in materials and activities, it was detected that the teachers had a positive attitude towards facilitating student learning and practice in the process. The teachers improved more qualified materials like a video, worksheets and games to reinforce the structure and vocabulary teaching especially in the last two research lesson. In this sense, it can be said that lesson study encourages the preparation of materials and enrich the teaching. Rachmajanti (2017) stated that lesson study improves English teachers' teaching material development skills. The findings comply with the study of Rachmajanti (2017). The teachers had problems with the timing in the first and second research lessons. These problems stem from factors such as the habit of preparing lesson plan (Gutierez, 2015), not making a temporal planning in their lessons before; lack of knowledge and skills in determining the content and not making pre-application. However, teachers were able to make right decisions cooperatively to determine the time in the last research lesson process thanks to reflection process and making the content simpler. In the process, the teachers made more general and specific decisions regarding possible positive and negative situations during the lesson. This finding stresses that teachers developed positive behaviour towards students learning. Lesson study process encourages teachers to plan the lesson by taking student answers, misunderstandings and incorrect answers into consideration (Batıbay, 2018; Harle, 2008). These research results support this finding. In the process, the team made a lesson plan that was more compatible with communicative language teaching principles by taking regulatory decisions for including four language skills in the same lesson, providing more rich examples of language use, and indirect teaching of language structures. This positive change may be the result of teachers' ability to critically analyze techniques and methods for teaching English and individual suggestions in a cooperative process. The study of Rahmawan, Hendayana, Hernani, and Rahayu (2019) supports these findings. Rubenwan et al. (2019) emphasized that teachers improve student learning by new teaching strategies during lesson study process. The team took constructive decisions in the preparatory activities to determine the steps of implementation by not writing the words on the board, acting flexible and making temporal decisions). On resource utilization, teachers could not include resources suitable for their purposes in the process. The cyclical process of the lesson study, observation notes, camera recordings, teachers' individual suggestion, reflection processes and cooperative working environment help teachers make more specific decisions. Suryani et 
al. (2017) detected cooperative activities of lesson study has a positive effect on the teaching practices of English teachers. Aimah and Purwant (2018) stated that lesson study process encourages English teachers to prepare better for their teaching tasks.

In this study, it was concluded that lesson study encourages English teachers to make effective decisions in preparatory activities for teaching duties; it has had a positive effect on teachers' knowledge and skills for course preparation and practice.

\section{ACKNOWLEDGEMENTS}

This article is a part of the first author's doctoral dissertation of the first author entitled as "Preparation and Reflection Activities of English Teachers for Teaching Tasks in the Context Of Lesson Study" in Konya Necmettin Erbakan University Institute of Education Science.

\section{REFERENCES}

Aimah, S., Ifadah, M., Bharati, L., \& Anggani, D. (2017). Building teacher's pedagogical competence and teaching improvement through lesson study. Arab World English Journal (AWEJ), 8(1), 66-78.

Aimah, S., \& Purwant, B. (2018). Indonesian teachers' perception on the implementation of lesson study: exploring teachers' awareness of pedagogical knowledge. Arab World English Journal (AWEJ) Volume, 9.

Angelini, M. L., \& Álvarez, N. (2018). Spreading lesson study in pre-service teacher instruction. International Journal for Lesson and Learning Studies, 7(1), 23-36.

Aykan, A. (2019). Öğretmen Adayları Açısından Ders Araştırması Modelinin Mesleki Gelişim Kapsamında Incelenmesi Yayınlanmamış doktora tezi, Tokat Gaziosmanpaşa Üniversitesi, Tokat, Türkiye.

Batıbay, G. (2018). Ders araştırmasıyla matematik öğretmenlerinin yaratıcı drama yöntemini kullanarak matematiği öğretme bilgilerinin gelişiminin incelenmesi Yayınlanmamış yüksek lisans tezi, Dokuz Eylül Üniversitesi, İzmir, Türkiye.

Bozkurt, E. (2015). Ders araştırması modeli bağlamında ortaokul matematik öğretmenlerinin öğretim faaliyetlerine yönelik grup temelli öz düzenlemelerinin incelenmesi. Yayınlanmamış doktora tezi, Hacettepe Üniversitesi, Ankara, Türkiye.

Büyüköztürk, Ş., Çakmak, E. K., Akgün, Ö. E., Karadeniz, Ş., \& Demirel, F. (2017). Bilimsel araştırma yöntemleri. Pegem Atıf indeksi, 1-360.

Cerbin, W., \& Kopp, B. (2006). Lesson study as a model for building pedagogical knowledge and improving teaching. International journal of teaching and learning in higher education, 18(3), 250-257.

Cheng, E. (2011). How lesson study develops pre-service teacher? Instructional design competency? The International Journal of Research and Review, 7(1), 67-79.

Cohan, A., \& Honigsfeld, A. (2006). Incorporating "lesson study" in teacher preparation. The Educational Forum, 71(1), 81-92.

Collet, V. S., \& Greiner, A. C. (2020). Revisioning grammar instruction through collaborative lesson study: A new apprenticeship of observation. Literacy Research and Instruction, 59(2), 95-126. 
Creswell, J. W. (2007). Qualitative inquiry and research design: Choosing among five approaches (Second ed.). London: Sage.

Fernandez, C., Cannon, J., \& Chokshi, S. (2003). A US-Japan lesson study collaboration reveals critical lenses for examining practice. Teaching and Teacher Education, 19(2), 171-185. doi:10.1016/S0742-051X(02)00102-6

Fernandez, C., \& Yoshida, M. (2004). Lesson Study: A Japanese approach to improving mathematics teaching and learning. New Jersey: Lawrence Erlbaum Associates.

Gök, S. Ö. (2016). Lesson study in ELT. Tesol Quarterly, 40(1), 235-257.

Guba, E. G., \& Lincoln, Y. S. (2001). Guidelines and checklist for constructivist (aka fourth generation) evaluation. In.

Gutierez, S. B. (2015). Collaborative professional learning through lesson study: Identifying the challenges of inquiry-based teaching. Issues in Educational Research, 25(2), 118.

Harle, C. B. (2008). The Lesson Study professional development process: Exploring the learning experiences of elementary and middle school teachers. (Unpublished Doctoral Dissertation 3344296), The University of Texas at Austin, Texas, United States Retrieved from http://search.proquest.com/docview/304158256?accountid=37146 ProQuest Dissertations \& Theses (PQDT) database.

Huang, R., Su, H., \& Xu, S. (2014). Developing teachers' and teaching researchers' professional competence in mathematics through Chinese Lesson Study. ZDM, 46(2), 239-251.

Johnson, K. E. (2006). The sociocultural turn and its challenges for second language teacher education. Tesol Quarterly, 40(1), 235-257.

Karabuğa, F., \& Ilin, G. (2019). Practicing lesson study in a Turkish education context: Considering the challenges, suggestions and benefits from EFL teachers' perspectives. International Journal for Lesson and Learning Studies, 8(1), 60-78.

Kükey, H. (2018). Illköğretim matematik öğretmen adaylarının 5. sınıf kesirler konusunda derse hazırlık süreçlerinin lesson study (Ders imecesi) modeli kapsamında incelenmesi Yayınlanmamış yüksek lisans tezi, İnönü Üniversitesi, Malatya, Türkiye,

Lee, J. F. (2008). A Hong Kong case of lesson study-Benefits and concerns. Teaching and Teacher Education, 24(5), 1115-1124.

Lewis, C. C. (2009). What is the nature of knowledge development in lesson study? Educational Action Research, 17(1), 95-110. doi:10.1080/09650790802667477

Loose, C. C. (2014). Japanese Lesson Study sustaining Teacher Learning in the Classroom Context.

Meyer, R. D. (2006). Lesson Study: The effects on teachers and students in urban middle schools. (Unpublished Doctoral Dissertation 3195279), Baylor University, Texas, United States Retrieved from http://search.proquest.com/docview/305355547?accountid=37146 ProQuest Dissertations \& Theses (PQDT) database.

Nami, F., Marandi, S. S., \& Sotoudehnama, E. (2016). CALL teacher professional growth through lesson study practice: an investigation into EFL teachers' perceptions. Computer Assisted Language Learning, 29(4), 658-682.

Peterson, P. L., Marx, R. W., \& Clark, C. M. (1978). Teacher planning, teacher behavior, and student achievement. American Educational Research Journal, 15(3), 417-432.

Rachmajanti, S. (2017). The Implementation of Lesson Study in Improving the Primary School English Teachers' Professionalism on Developing Materials. Paper presented at the International Conference on Education (ICE2) 2018: Education and Innovation in Science in the Digital Era.

Rahmawan, S., Hendayana, S., Hernani, H., \& Rahayu, D. (2019). Exploring the effect of reflection to inquiry teaching through lesson study for learning community. Paper presented at the Journal of Physics: Conference Series. 
Reese, C. D. (2011). Latino English Language Learners in Middle School and the Effect of General Education Teachers' Use of the Lesson Study Collaborative Model.

Sims, L., \& Walsh, D. (2009). Lesson study with preservice teachers: Lessons from lessons. Teaching and Teacher Education, 25(5), 724-733.

Sönmez, V. (2015). Öğretmen el kitabı. Ankara: Anı.

Sönmez, V., \& Alacapınar, F. G. (2016). Bilimsel araştırma yöntemleri (4. ed.). Ankara: Anı.

Sponsel, B. J. (2010). The impact of the infinite mathematics project on teachers' knowledge and teaching practice: A case study of a title IIB MSP professional development initiative. (Unpublished Doctoral Dissertation 3438642), Kansas State University, Kansas, United States. Retrieved from http://search.proquest.com/docview/847949481?accountid=37146 ProQuest Dissertations \& Theses (PQDT) database.

Stepanek, J., Appel, G., Leong, M., Mangan, M. T., \& Mitchell, M. (2007). Leading Lesson Study: A practical guide for teachers and facilitators: Corwin Press Thousand Oaks, CA.

Suryani, F., Rukmini, D., L.B. Angani, D., \& Hartono, R. (2017). Enhancing EFL student teachers' teaching practice through microteaching lesson study. Asian Journal of Educational Research, 5(2).

Tasker, T. C. (2014). Exploring EFL teacher professional development through lesson study: An activity theoretical approach., Unpublished doctoral thesis. The Pennsylvania State University.

Yetkin-Özdemir, I. E., Akdal, P., Bozkurt, E., \& Gürel, R. (2015, 14-16 Mayıs). Göreve yeni başlayan ortaokul matematik öğretmenlerinin öğretim hedefleri Paper presented at the 14 . Matematik Eğitimi Sempozyumu, Niğde.

Yildirim, A. (2003). Instructional planning in a centralized school system: Lessons of a study among primary school teachers in Turkey. International Review of Education, 49(5), 525-543.

Yoshida, M. (1999). Lesson Study: A case study of a Japanese approach to improving instruction through school-based teacher development. (Unpublished Doctoral Dissertation 9951855), The University of Chicago, Illinois, United States. Retrieved from http://search.proquest.com/docview/304542455?accountid $=37146 \quad$ ProQuest Dissertations \& Theses (PQDT) database.

Zahorik, J. A. (1975). Teachers' planning models. Educational Leadership, 33(2), 134-139.

\section{Biographical notes:}

Gökhan ORHAN graduated from Atatürk University Faculty of Education, Department of English Language Education in 2007. In 2013, He took master's degree in Department of Educational Sciences, Curriculum and Instruction Program at Gaziosmanpaşa University and Ph.D. degree at Necmettin Erbakan University. He has been teaching English at the Ministry of National Education since 2007. He has studies in English teaching and learning, education sciences, distance learning and teacher education.

Prof. Dr. Ömer BEYHAN obtained master's degree and Ph.D. degree in Department of Educational Sciences, Curriculum and Instruction Program from Selçuk University. He became an associate professor in 2014. Since 2019, He has been working as a professor in Department of Educational Sciences in Ahmet Keleşoğlu Education Faculty of Necmettin Erbakan University. 